\title{
An aerobic granular sludge process for treating low carbon/ nitrogen ratio sewage
}

\author{
JaeBin Yae ${ }^{1}$, JaeHoon Ryu ${ }^{1}$, Nguyen Van Tuyen ${ }^{1}$, HyunGu Kim², SeongWan Hong ${ }^{1,2}$, DaeHee Ahn ${ }^{1,2^{\dagger}}$ \\ ${ }^{1}$ Department of Environmental Engineering and Energy, Myongji University, Yongin 17058, Republic of Korea \\ ${ }^{2}$ BlueBank Co., Ltd., Business Incubator Center, Myongji University, Yongin 17058, Republic of Korea
}

\begin{abstract}
This study investigated the characteristic of aerobic granular sludge (AGS) process to treat the sewage having low carbon/nitrogen ratio (Biochemical oxygen demand $\left(\mathrm{BOD}_{5}\right)$ :Total nitrogen $\left.(\mathrm{T}-\mathrm{N}), 4.5: 1\right)$ in sequencing batch reactor (SBR). The removal efficiency of $\mathrm{BOD}_{5}$, suspended solid (SS), T-N and phosphorus $\left(\mathrm{PO}_{4}^{3-}-\mathrm{P}\right)$ were $92.6 \%, 64.3 \%$ and $90.1 \%$. Concentration and size of AGS were changed in proportion to the organic matters and nitrogen concentration of the influent (Concentration and size of AGS: 1,700-3,000 mg/L, 0.5-1.0 mm). Mixed liquor suspended solid (MLSS) also changed with the concentration of AGS (MLSS: 2,000-3,500 mg/L). When the settling time was shortened from $15 \mathrm{~min}$ to $10 \mathrm{~min}$, size and shape of AGS were maintained (Size of AGS: 1.0-1.5 mm). In addition, the concentration of AGS and MLSS increased (Concentration of AGS: 3,500 mg/L, MLSS: 4,000 mg/L). Concentration, size and shape of AGS were affected the settling time of the reactor more than the concentration of organic matter and nitrogen in the influent. In the results of removal efficiency and changes in AGS, we confirmed that the SBR process using AGS can be used to treat the sewage having low carbon/nitrogen ratio by applying short settling time.
\end{abstract}

Keywords: Aerobic granular sludge (AGS), Low carbon/nitrogen ratio, Sequencing batch reactor (SBR), Sewage

\section{Introduction}

Sewage treatment is required advanced technology to replace the existing activated sludge process in order to meet the effluent water quality standard which can be strengthened in the future. Recent techniques are preferred for modifying the existing infrastructure, instead of increasing the capacity of the bioreactor or adding machinery, taking into account limited space and economics. The newly constructing sewage treatment facility can reduce the capacity of the bioreactor by decreasing the process time. For example, the method can decline the capacity of the bioreactor by a shortening of settling time [1], simultaneous removal of nitrogen and phosphorus [2], and simultaneous nitrification and denitrification [3].

Aerobic granular sludge (AGS) is a spherical biomass formed by self-immobilization without carriers under aerobic conditions. AGS has been studied to treat wastewater of various characteristics since the late 1980s [4-6], and it is considered as an alternative to replace the existing activated sludge process due to its many advantages [7]. de Bruin et al. [8] reported that the settling velocity of AGS is high so that a separate settling tank is not needed, and the facility area can be reduced by $80 \%$. In practice, there are many cases where AGS is being applied to full-scale facilities overseas [9-11]. The existing activated sludge process has advantages of easy operation and low price, but it has problems such as bulking and rising of sludge. AGS can simultaneously remove biological phosphate and nitrogen by the oxygen gradient in the granule [8]. Also AGS is a promising technology with advantages such as good settling velocity and high biomass [12]. Therefore, AGS technology provides a solution to solve the problems of the activated sludge process. For AGS technology, Tay et al. [13] reported that it is hard to form granules with organic loading rate (OLR) less than $2 \mathrm{~kg} \mathrm{COD} / \mathrm{m}^{3} / \mathrm{d}$. Because there is still an incomplete understanding of the parameters that drive the formation of AGS, some researchers have reported that AGS is not as practical as activated sludge [11, 14]. In addition, it is difficult to find a pilot-scale facility using AGS in Korea.

On the other hand, the biological treatment process is known to have a carbon/nitrogen ratio of about 20:1 for optimum influent sewage under aerobic conditions [15]. However, the average biochemical oxygen demand $\left(\mathrm{BOD}_{5}\right)$ and total nitrogen $(\mathrm{T}-\mathrm{N})$ concentration are 137.9 $\mathrm{mg} / \mathrm{L}$ and $37.2 \mathrm{mg} / \mathrm{L}$ in Korea [16], resulting in a carbon/nitrogen
This is an Open Access article distributed under the terms of the Creative Commons Attribution Non-Commercial License (http://creativecommons.org/licenses/by-nc/3.0/) which permits unrestricted non-commercial use, distribution, and reproduction in any medium, provided the original work is properly cited.

Copyright (C) 2019 Korean Society of Environmental Engineers
Received November 19, 2017 Accepted July 26, 2018

${ }^{\dagger}$ Corresponding author

Email: dhahn@mju.ac.kr

Tel: +82-31-321-5901 Fax: +82-505-300-5901

ORCID: 0000-0002-6031-3610 
ratio of 3.71. For this reason, it is recognized that it would be very difficult to apply AGS to sewage treatment in Korea.

Therefore, we confirmed the biological treatment efficiency in the pilot scale facility using AGS and observed the morphological changes of the sludge. Furthermore, differences in microbial community between AGS and activated sludge were carried out through pyro-sequencing.

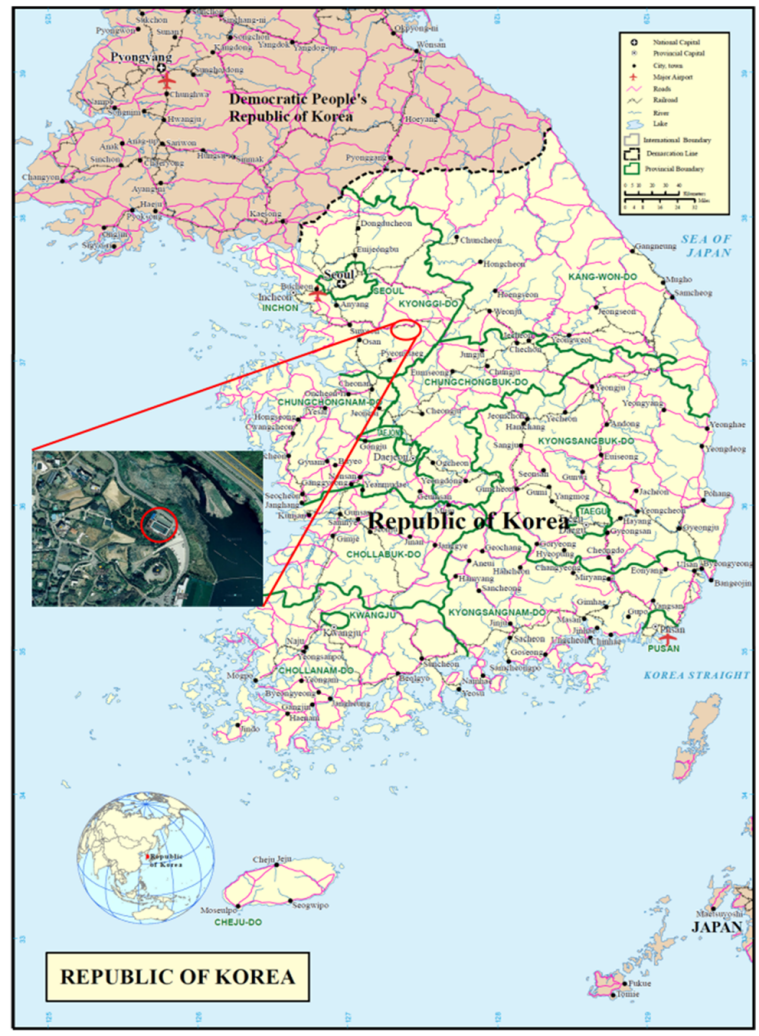

Fig. 1. Location of $\mathrm{K}$ small scale sewage treatment plant.

\section{Materials and Methods}

\subsection{Description of the Plant}

This study was performed with the pilot scale the AGS process at the $\mathrm{K}$ small scale sewage treatment plant in Yongin City of Korea (Fig. 1). As shown in Fig. 2, the pilot plant of this study is divided into equalization tank, bio-reactor, multi-functional tank, and effluent tank, respectively.

The volume of bio-reactor was $75 \mathrm{~m}^{3}$ and the exchange rate was $50 \%$. The operation cycle of bio-reactor was 4 cycle/d for adaptation of AGS, and 6 cycle/d after a start-up period of 60 d. The influent flow rate of bio-reactor was $225 \mathrm{~m}^{3} / \mathrm{d}$.

Dissolved oxygen (DO) and $\mathrm{pH}$, which were online monitored, but not controlled along the whole experimental period with Hach-Lange probes, ranged typically from 0.2 to $4.12 \mathrm{mg} \mathrm{O}_{2} / \mathrm{L}$ and from 6.6 to 7.5 , respectively.

The initial concentration of mixed liquor suspended solid (MLSS) in the bio-reactor was $2,000 \mathrm{mg} / \mathrm{L}$ and sludge volume index $\left(\mathrm{SVI}_{30}\right)$ was $50 \mathrm{~mL} / \mathrm{g}$. And the AGS larger than $0.2 \mathrm{~mm}$ was made in the factory and seeded to the reactor during the start-up period.

\subsection{Wastewater Composition}

The influent was sewage in the flow control tank of the $\mathrm{K}$ small scale sewage treatment plant located in Yongin City of Korea. The average concentration of the influent was $\mathrm{BOD}_{5} 105.4 \mathrm{mg} / \mathrm{L}$, suspended solid (SS) $49.4 \mathrm{mg} / \mathrm{L}$, T-N $23.4 \mathrm{mg} / \mathrm{L}$ and PO4 ${ }^{3-}-\mathrm{P} 1.37$ $\mathrm{mg} / \mathrm{L}$ (Table 1). The influent carbon/nitrogen ratio was 4.5:1 (BOD $: \mathrm{T}-\mathrm{N})$.

The concentration of organic matters and nitrogen of the influent remained low during the winter and increased with the growth of temperature after March. After that, it decreased during the rainy season (Fig. 3). The temperature of influent had less than $8^{\circ} \mathrm{C}$ from December 16, 2015 to February 24, 2016 (Fig. 4).

\section{Chemical additive tank}

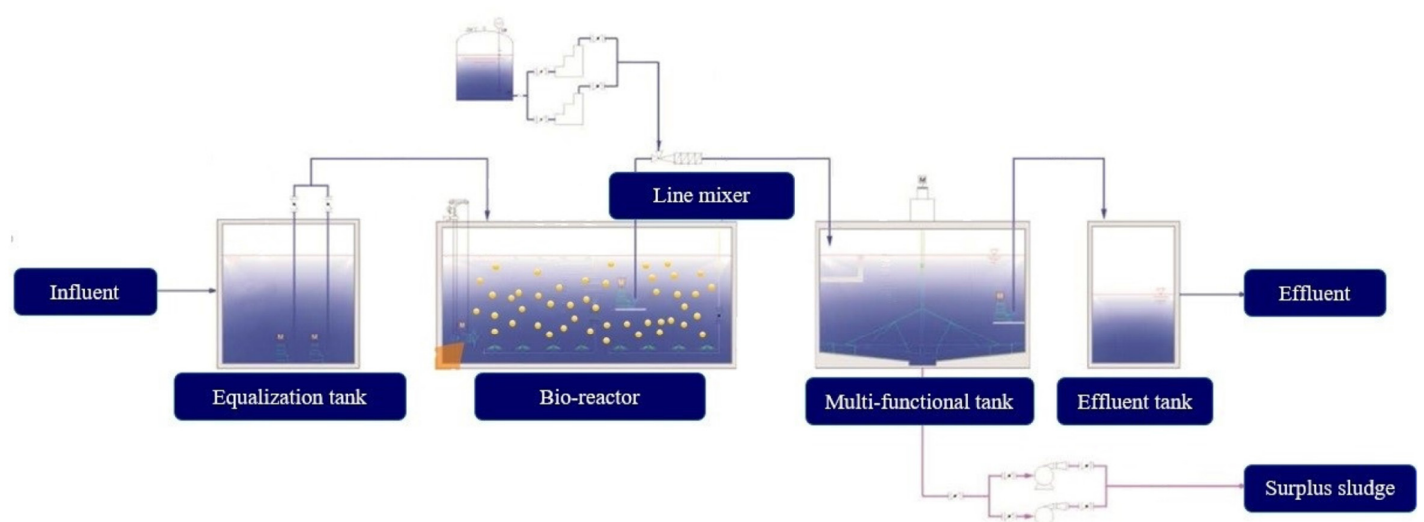

Fig. 2. Schematic diagram of the AGS-SBR process (Equalization tank: $1.5 \mathrm{~m} \mathrm{~W} \times 3.6 \mathrm{~m} \mathrm{~L} \times 5.0 \mathrm{~m} \mathrm{H}$, Bio-reactor: $4.6 \mathrm{~m} \mathrm{~W} \times 3.6 \mathrm{~m} \mathrm{~L}$ $\times 5.0 \mathrm{~m} \mathrm{H}$, Multi-functional tank: $3.6 \mathrm{~m} \mathrm{~W} \times 3.6 \mathrm{~m} \mathrm{~L} \times 5.0 \mathrm{~m} \mathrm{H}$, Effluent tank: $1.5 \mathrm{~m} \mathrm{~W} \times 3.6 \mathrm{~m} \mathrm{~L} \times 5.0 \mathrm{~m} \mathrm{H}$, (W: Width, L: Length, $\mathrm{H}$ : Height)). 
Table 1. Characteristics of Influent during Operation Time

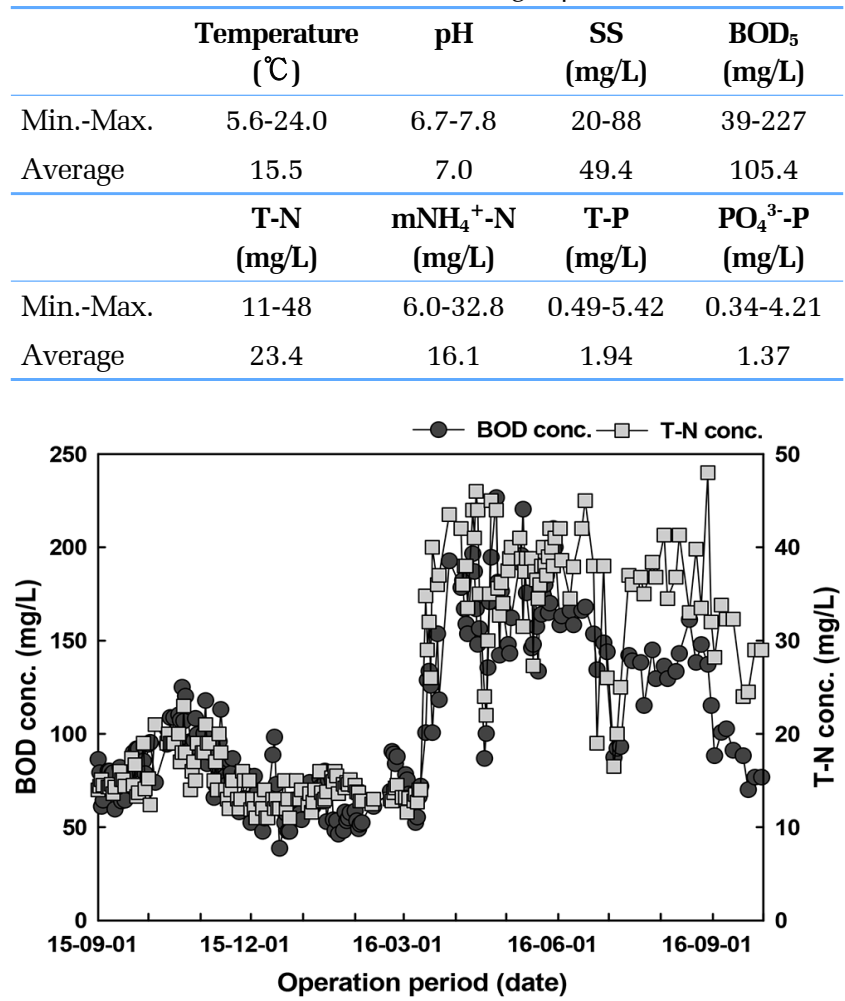

Fig. 3. $\mathrm{BOD}_{5}$, and $\mathrm{T}-\mathrm{N}$ concentration of influent during operation time.

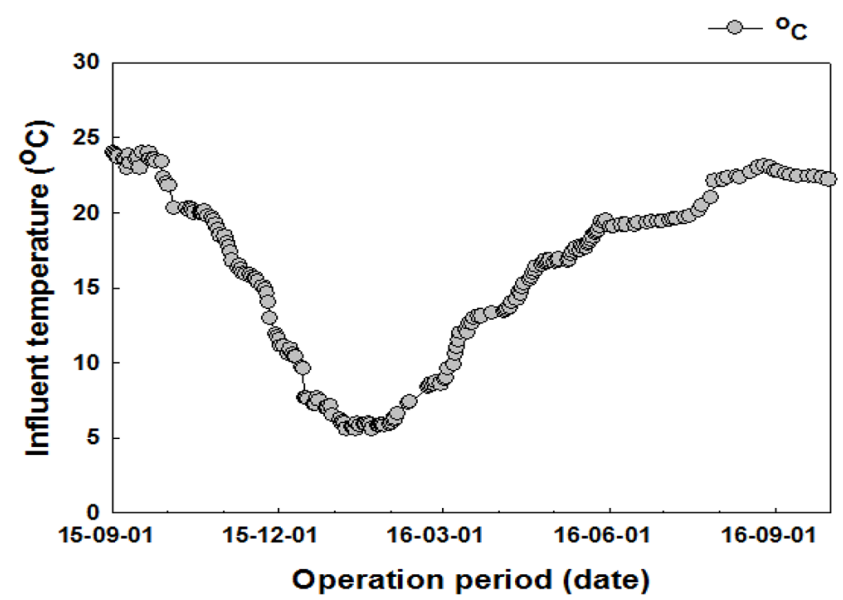

Fig. 4. Temperature of influent during operation time.

\subsection{Operating Condition}

The bio-reactor was operated as the sequencing batch process mode. The sequencing batch reactor (SBR) has a unique operating feature that is alternating anaerobic/anoxic/aerobic environments to meet the needs of activities of microorganisms so that nitrification and denitrification can occur during the aerobic and the anoxic stage, respectively [17].

A total operation period was from Sep. 1, 2015 to Sep. 30, 2016. During the start-up periods, the time per cycle in the bio-reactor was $60 \mathrm{~min}$ for inflow, $240 \mathrm{~min}$ for aeration and $60 \mathrm{~min}$ for settling
\& outflow (Phase 1).

After the start-up periods, the time per 1 cycle in the bio-reactor was $60 \mathrm{~min}$ for inflow, $120 \mathrm{~min}$ for aeration and $60 \mathrm{~min}$ for settling \& outflow (Phase 2, 3).

During the last two months of an operation period, the settling time was divided into $15 \mathrm{~min}$ (phase 2) and $10 \mathrm{~min}$ (phase 3) to confirm the settling characteristics of AGS (Table 2).

Table 2. The Time per 1 Cycle of the AGS-SBR Process

\begin{tabular}{lccccc}
\hline & $\begin{array}{c}\text { Operation time } \\
\text { (d) }\end{array}$ & $\begin{array}{c}\text { Inflow } \\
\text { (min) }\end{array}$ & $\begin{array}{c}\text { Aeration } \\
\text { (min) }\end{array}$ & $\begin{array}{c}\text { Settling } \\
\text { (min) }\end{array}$ & $\begin{array}{c}\text { Outflow } \\
\text { (min) }\end{array}$ \\
\hline phase 1 & Start-61 & 60 & 240 & 15 & 45 \\
\hline phase 2 & $61-334$ & 60 & 120 & 15 & 45 \\
\hline phase 3 & $334-e n d$ & 60 & 120 & 10 & 50 \\
\hline
\end{tabular}

\subsection{Analytical Methods}

A soluble sample of water quality analysis was filtered by a glass microfiber filter (Whatman; International Ltd., $0.45 \mathrm{~mm} \mathrm{GF} / \mathrm{C}$ ). $\mathrm{BOD}_{5}, \mathrm{~T}-\mathrm{N}, \mathrm{PO}_{4}{ }^{3-}-\mathrm{P}$, and solid were analyzed to base on standard methods [18]. The ammonium nitrogen was analyzed by a spectrophotometer (DR-2500, Method 8038, Hach Co., USA). To observe the nutrient treatment efficiency, influent and effluent water quality analysis was conducted five times a week. The morphological characteristics of AGS were observed the changes in size, surface and morphology during the operation period through optical microscope (OLYMPUS CX31) and environmental scanning electron microscope (E-SEM) (Model XL-30 ESEM-FEG, FEI, USA).

To observe the microbial community was performed the pyrosequencing data analysis. The community analysis was performed to determine the characteristics of AGS and the difference in activated sludge. Each sludge was homogenized using homogenizer. The sample was centrifuged to discard the supernatant, and DNA extraction was performed. DNA extraction was performed using FastDNA SPIN Kit for soil (MP Bio, Santa Ana, Calif., USA). Polymerase chain reaction (PCR) (C1000 Touch thermal cycler, Bio-Rad, Hercules, CA, USA) was used 1 microliter of extracted DNA and initial denaturation was performed $95^{\circ} \mathrm{C}$ for $5 \mathrm{~min}$. After the procedure was followed by 30 cycles of denaturation $\left(95^{\circ} \mathrm{C}\right.$, $30 \mathrm{~min})$, annealing $\left(55^{\circ} \mathrm{C}, 30 \mathrm{~s}\right)$, extension $\left(72^{\circ} \mathrm{C}, 30 \mathrm{~s}\right)$, and final extension $\left(72^{\circ} \mathrm{C}, 7 \mathrm{~min}\right)$, respectively, and fixed at $4^{\circ} \mathrm{C}$. For successful PCR, the purity of the DNA was increased using QIAquick PCR purification kit (Qiagen, Calencia, CA, USA). Pyrosequencing (454 GS FLX Junior Sequencing System, Roche, Branford, CT, USA) was conducted to using amplified DNA samples.

\section{Results and Discussion}

\subsection{Process Performance of AGS-SBR}

The concentration of influent, effluent and removal efficiency of $\mathrm{BOD}_{5}$, SS, T-N and $\mathrm{PO}_{4}{ }^{3-}-\mathrm{P}$ during the operation period were shown through Fig. 5 to 8, respectively. The AGS has substrate gradients, which in turn results in different layered structures with different functions [19-20]. Studies have shown that aerobic and anaerobic metabolic activities can co-exist in the granule, like the simultaneous 
removal of organic matters, nitrogen and phosphorus [2, 21-22], or simultaneous nitrification and denitrification [23-24]. In this study, the effluent concentration of $\mathrm{BOD}_{5}$ was $4.2-10.4 \mathrm{mg} / \mathrm{L}, 6.5$ $\mathrm{mg} / \mathrm{L}$ on average and the removal efficiency was $92.6 \%$. T-N showed a low removal efficiency during the winter season because it was influenced by temperature. But the effluent concentration of T-N was not high so it satisfied the discharged effluent standard (BOD ${ }_{5}$ : $10 \mathrm{mg} / \mathrm{L}$, SS: $10 \mathrm{mg} / \mathrm{L}, \mathrm{T}-\mathrm{N}: 20 \mathrm{mg} / \mathrm{L}$, Total phosphorus (T-P): 2 $\mathrm{mg} / \mathrm{L}$ [25]). During the operation period, the effluent concentration of T-N was $2.1-13.1 \mathrm{mg} / \mathrm{L}, 8.3 \mathrm{mg} / \mathrm{L}$ on average, and the removal efficiency of T-N was $64.3 \%$. The effluent concentration of $\mathrm{PO}_{4}{ }^{3-}-\mathrm{P}$ was $0.01-1.28 \mathrm{mg} / \mathrm{L}, 0.14 \mathrm{mg} / \mathrm{L}$ on average and the removal efficiency of $\mathrm{PO}_{4}{ }^{3-}-\mathrm{P}$ was $90.1 \%$. Generally, phosphorus is removed through cell synthesis and sludge removal. A chemical (PAC, Poly-Aluminum Chloride) was also injected into the Multi-functional tank through the line mixer for the phosphorus removal. However, the settleability of the AGS $\left(\mathrm{SVI}_{30}: 50-70 \mathrm{~mL} / \mathrm{g}\right)$ was better than the activated sludge $\left(\mathrm{SVI}_{30}\right.$ : $50-150 \mathrm{~mL} / \mathrm{g}$, [26]); Therefore, the amount of chemical of injection for sludge removal was low (6.01 $\mathrm{kg} / \mathrm{d}$ ). And the effluent concentration of SS was $1-20 \mathrm{mg} / \mathrm{L}, 5.94 \mathrm{mg} / \mathrm{L}$

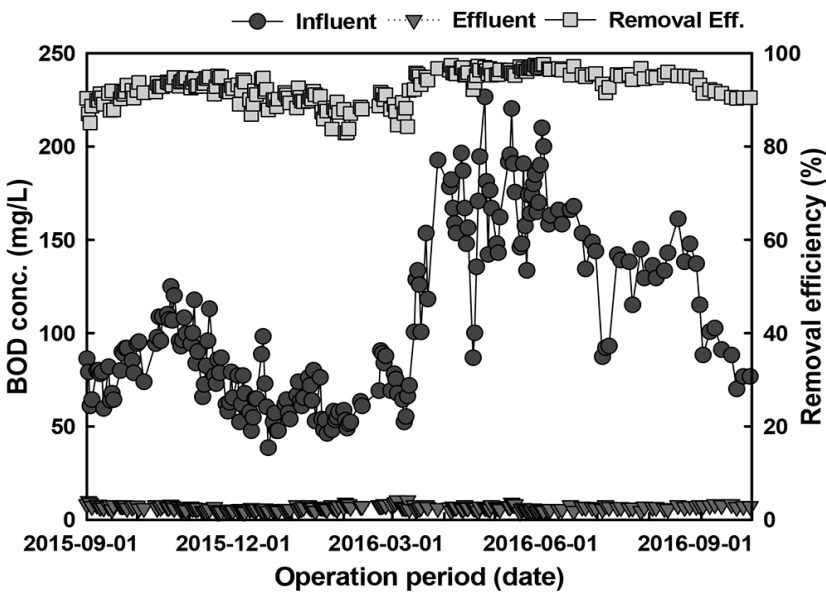

Fig. 5. $\mathrm{BOD}_{5}$ concentration of influent, effluent and removal efficiency during operation time.

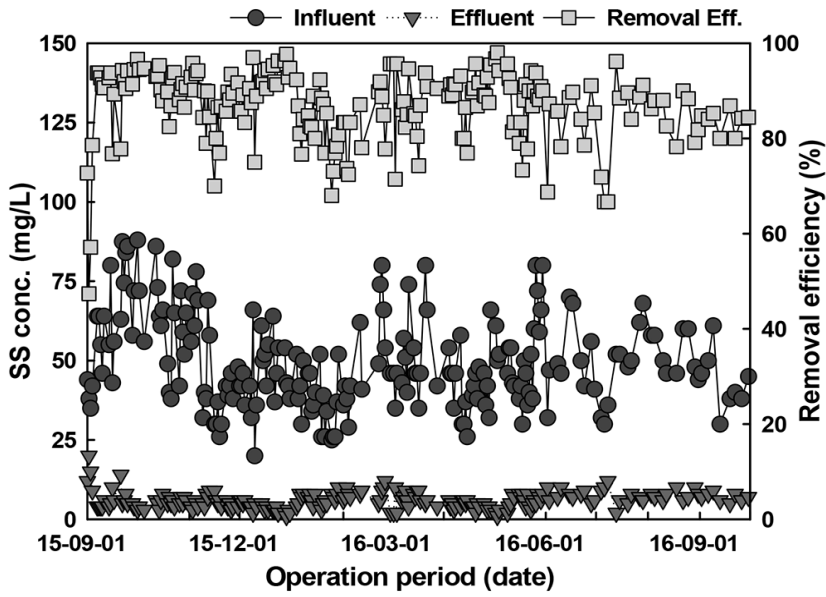

Fig. 6. SS concentration of influent, effluent and removal efficiency during operation time.

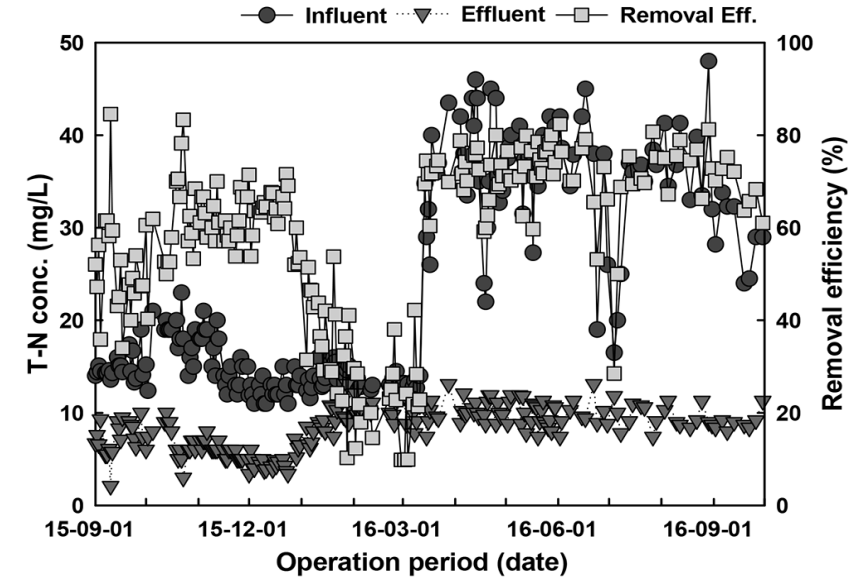

Fig. 7. T-N concentration of influent, effluent and removal efficiency during operation time.

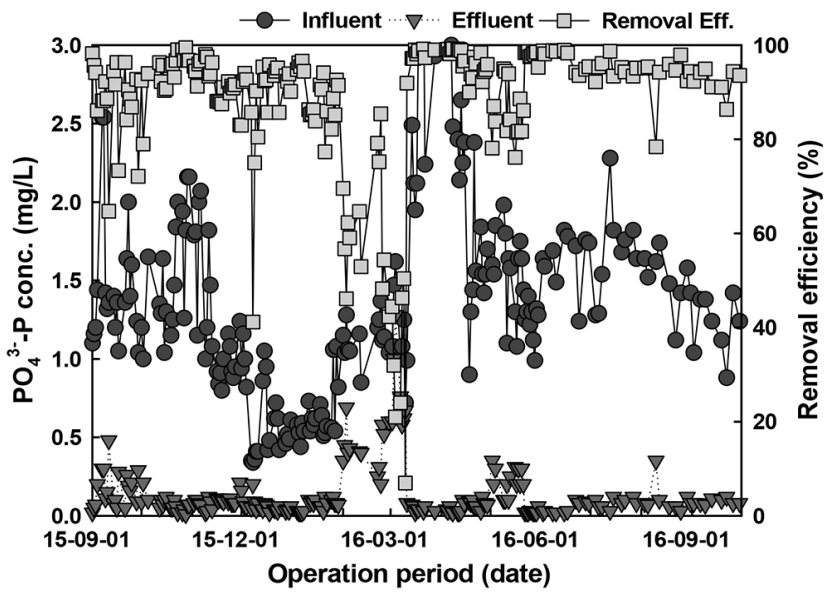

Fig. 8. $\mathrm{PO}_{4}{ }^{3-}-\mathrm{P}$ concentration of influent, effluent and removal efficiency during operation time.

on average and removal efficiency was $88.0 \%$. The influent concentration of SS was significantly changed and the settling time of the process was short. But because of an excellent settleability of AGS $\left(\mathrm{SVI}_{30}: 50-70 \mathrm{~mL} / \mathrm{g}\right)$, low effluent concentration of SS could be maintained. Consequently, the effluent concentration of $\mathrm{BOD}_{5}, \mathrm{~T}-\mathrm{N}$, $\mathrm{PO}_{4}{ }^{3-}-\mathrm{P}$ and SS satisfied the discharged effluent standard stably [25].

Increasing the organic concentration of the influent increases size and density of AGS, but it decreases the species diversity within AGS and accelerates the growth of the amount of microorganisms and relatively loose AGS is formed [6]. In this study, the concentration of AGS was increased or decreased according to the change of organic matters and nitrogen concentration in the influent from September 1, 2015 to July 31, 2016 (concentration of AGS: 1,700-3,000 mg/L). Excessive organic load promotes the growth of filamentous microorganisms. Especially, rapid growth of filamentous microorganisms can degrade the settleability of AGS and make it difficult to operate [27].

Settling time has a great influence on the formation of AGS. The SBR with long settling time does not successfully lead to 


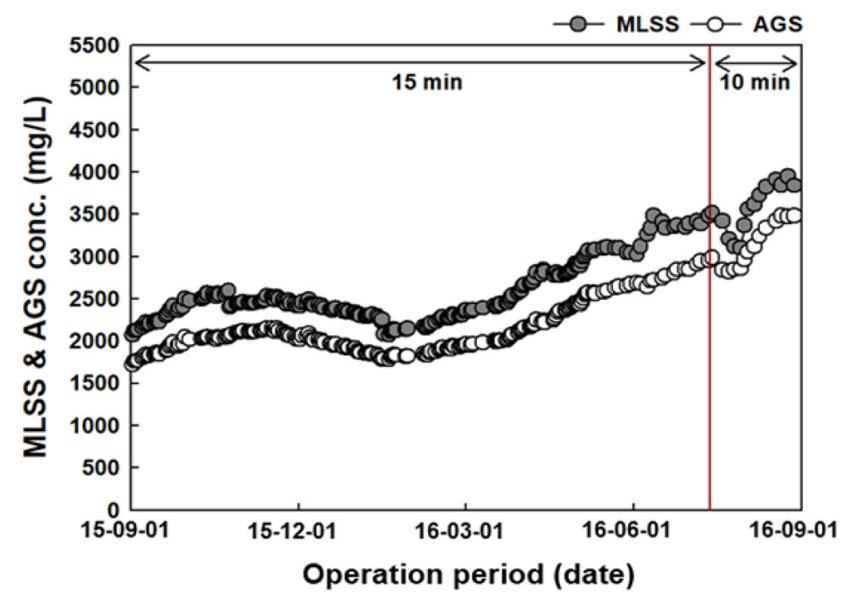

Fig. 9. MLSS and AGS concentration profiles during operation time.

the formation of AGS. Qin et al. [28] operated the SBR under the same conditions ( $4 \mathrm{~h} /$ cycle, $5 \mathrm{~min}$ for inflow, $5 \mathrm{~min}$ for outflow) except the settling times which were set to 5, 10, 15, and $20 \mathrm{~min}$ in four reactors and after an operation period, the ratio of AGS in the reactor was $100 \%, 35 \%, 15 \%$, and $10 \%$, respectively [28].
In this study, the settling time was adjusted from $15 \mathrm{~min}$ to 10 min from August 1, 2016 to September 30, 2016, to prevent the growth of filamentous microorganisms and successfully form the AGS. Initially, when the settling time decreased, the concentration of AGS was reduced to $2,800 \mathrm{mg} / \mathrm{L}$ because the AGS with poor settleability was discharged outside the bio-reactor. Thereafter, the remaining the AGS with good settleability grew in the reactor and the concentration of AGS went up to $3,500 \mathrm{mg} / \mathrm{L}$. As a result, the concentration of MLSS also increased to 4,000 mg/L (Fig. 9).

\subsection{Microscopic and E-SEM Observations of AGS}

Microscopic observations were carried out with an optical microscope. Microscopic observations showed that the size of AGS decreased after seeding. As the concentration of organic matter and nitrogen in the influent increased during May, June and July, the size of AGS increased and the shape of AGS remained denser. After reducing the settling time in August, although the concentration of organic matter and nitrogen in the influent decreased, size and shape of AGS did not change. To summarize, size and shape of AGS were affected by the settling time of the reactor than the concentration of organic matter and nitrogen in the influent (Fig. 10).
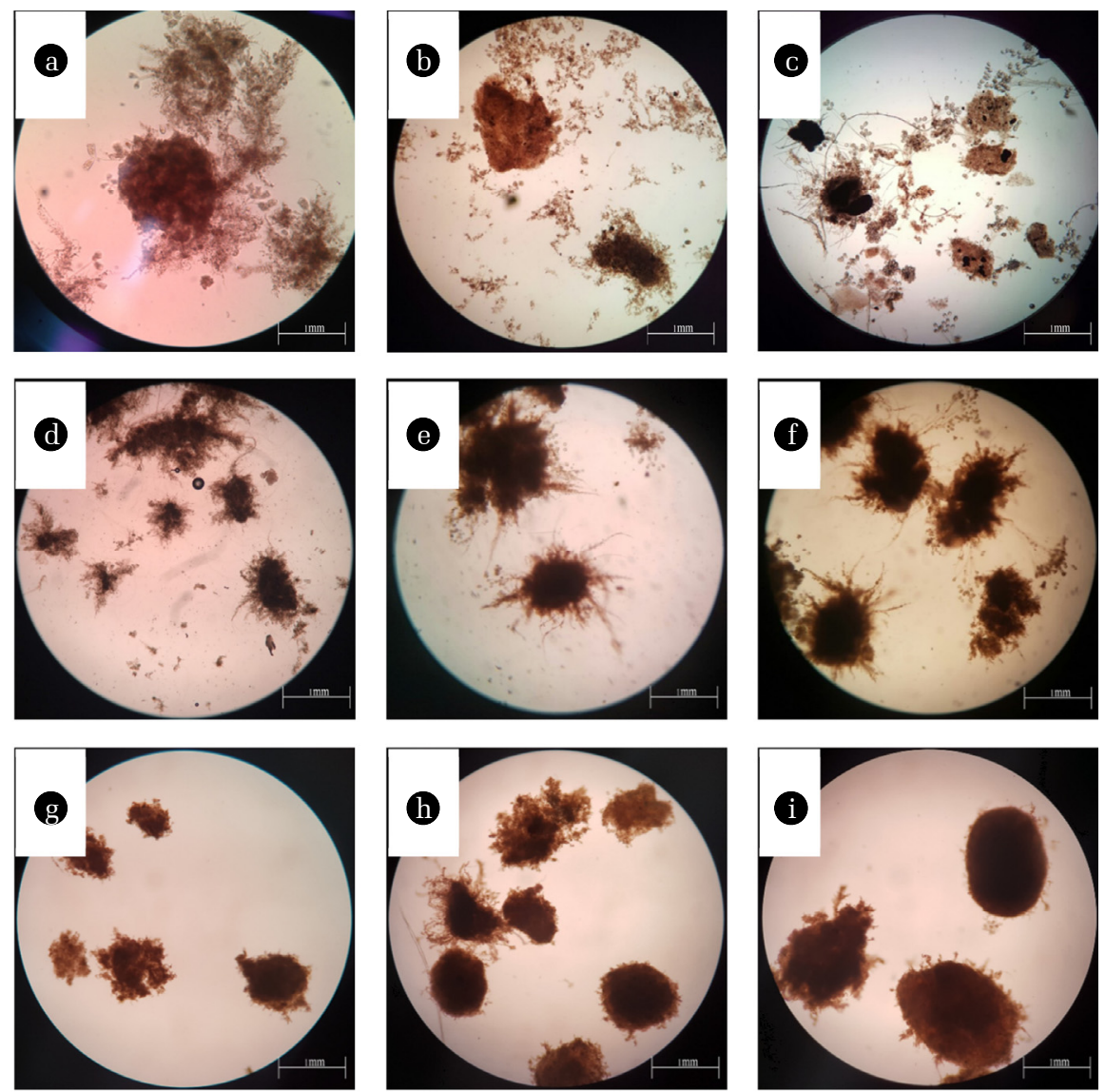

Fig. 10. Morphology observation of AGS during the operation period using microscope, ((a): October, (b): December, (c): February, (d): April, (e): June, (f): August and (g), (h), (i): Photographs of AGS in final operation day ((g): 0.5-0.6 mm, (h): 0.6-0.8 mm, (i): > 0.8 mm) $(\times 40$ magnification by optical microscope)). 
The surface and morphology of AGS were observed by using E-SEM. (a), (b), and (c) in Fig. 11 are the AGS which is larger than $1.0 \mathrm{~mm}$ in the bio-reactor of this study during the operation period ((a): November, (b): March and (c): July). In the observed images, the shape of AGS was close to spherical. The surface of AGS initially had a rough, irregular and fine-grained porous structure, but gradually turned into a smoother shape during the operation period.
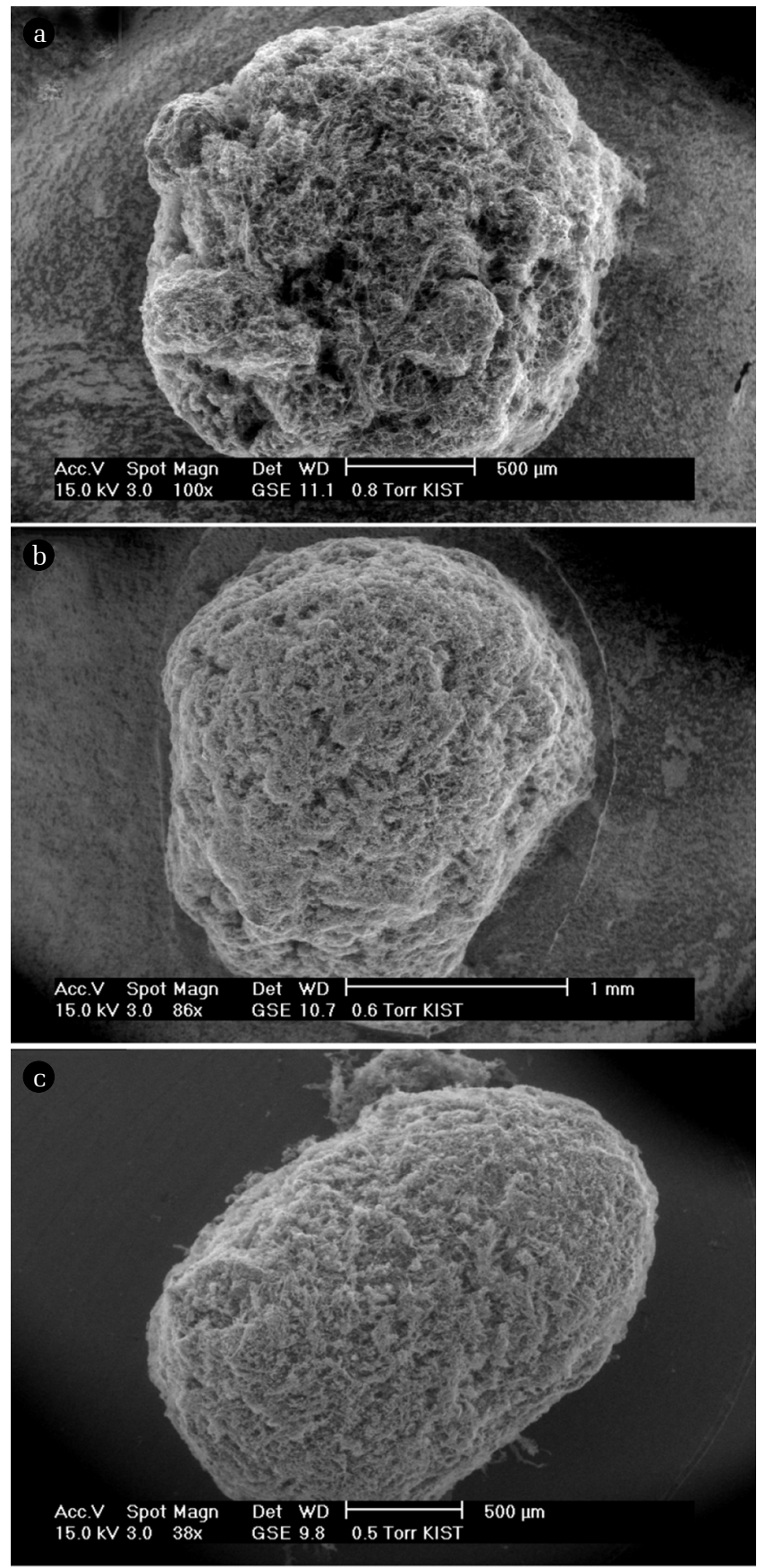

Fig. 11. Granule morphology of AGS using E-SEM, ((a): November, (b): March and (c): July).

\subsection{Microbial Community Analysis of AGS}

The microbial community analysis was performed to confirm the characteristics of AGS and the difference between AGS and activated sludge. Fig. 12 shows the pyrosequencing results of AGS and activated sludge using a dynamic pie chart (Krona). Table 3 is compared the abundance of microbial of phosphorus removal and nitrifying bacteria in AGS and activated sludge. Microbial analysis of the two sludges showed the highest Proteobacteria, and AGS and activated sludge were $45 \%$ and $43 \%$, respectively. Betaproteobacteria account for the highest percentage in the Proteobacteria community ( $37 \%$ AGS, and $48 \%$ activated sludge). They are known to be dominated in the wastewater treatment process [29]. They are also known to play a role of phosphorus removal [30]. Dechloromonas has been reported to remove as like Accumulibacter [31], and Thauera is known to carry out denitrification but has also been shown to remove phosphorus [32].

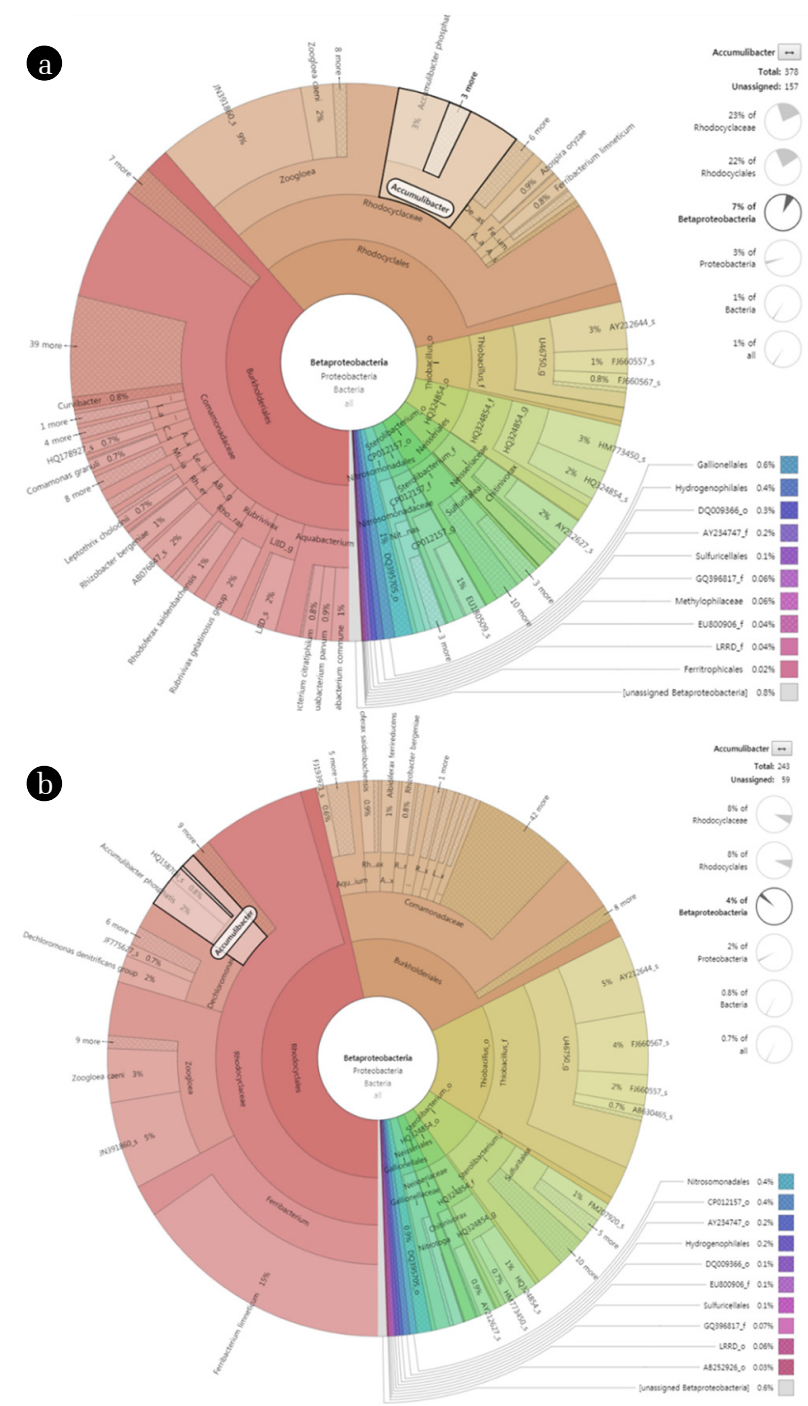

Fig. 12. The comparison of Accumulibacter in total fraction using dynamic pie chart (Krona). AGS (a) and activated sludge (b). 
Table 3. The Comparison of Microbial Communities in Betaproteobacteria Group

\begin{tabular}{|c|c|c|c|c|}
\hline \multirow{2}{*}{ Class } & \multirow{2}{*}{ Family } & \multirow{2}{*}{ Genus } & \multicolumn{2}{|c|}{ Abundance (\%) } \\
\hline & & & AGS & Activated sludge \\
\hline \multirow{5}{*}{ Betaproteobacteria } & \multirow{4}{*}{ Rhodocyclaceae } & Accumulibacter & 7.0 & 4.0 \\
\hline & & Dechloromonas & 2.0 & 5.0 \\
\hline & & Propionivibrio & 0.2 & 0.09 \\
\hline & & Thauera & 0.04 & 0.06 \\
\hline & Nitrosomonadales & Nitrosomonas & 2.0 & 0.2 \\
\hline
\end{tabular}

Bactereotides and Chloroflexi are known as anaerobic microorganisms [33], AGS and activated sludge were $30 \%$ and $31 \%$, respectively. The microorganisms related to nitrification were $2.0 \%$ of AGS and $0.2 \%$ of activated sludge in Betaproteobacteria microorganisms. Therefore, AGS was able to identify various microbial communities than activated sludge. On the other hand, this diversity is judged by the difference between AGS size and specific surface area. Because AGS differs in oxygen permeability and concentration gradient depending on particle size [2]. Also the differences in sludge gradient and microenvironment seem to affect the microbial growth environment.

\section{Conclusions}

In the AGS process using the SBR, concentration and size of AGS were changed in proportion to the organic matters and nitrogen concentration of the influent (concentration and size of AGS: 1,700-3,000 mg/L, 0.5-1.0 mm). MLSS also changed with the concentration of AGS (MLSS: 2,000-3,500 mg/L). When the settling time was shortened from $15 \mathrm{~min}$ to $10 \mathrm{~min}$ in August, the concentration of organic matter and nitrogen in the influent decreased. However, size and shape of AGS were maintained (Size of AGS: 1.0-1.5 mm). In addition, the concentration of AGS increased ( $>3,500 \mathrm{mg} / \mathrm{L})$ as the remaining AGS with good settleability grew in the reactor, meanwhile, the MLSS in the bio-reactor also increased $>4,000$ $\mathrm{mg} / \mathrm{L})$. Therefore, size and shape of AGS were affected the settling time of the reactor more than the concentration of organic matter and nitrogen in the influent. The removal efficiency of $\mathrm{BOD}_{5}, \mathrm{SS}$, T-N and $\mathrm{PO}_{4}{ }^{3-}-\mathrm{P}$ were $92.6 \%, 64.3 \%$ and $90.1 \%$ and the average effluent concentration of $\mathrm{BOD}_{5}, \mathrm{SS}$, T-N and $\mathrm{PO}_{4}{ }^{3-}-\mathrm{P}(6.5,6,8.3$, $0.14 \mathrm{mg} / \mathrm{L}$ ) satisfied the discharged effluent standard [25].

The bacteria related to phosphorus removal in Betaproteobacteria were $9.24 \%$ of AGS and $9.15 \%$ of activated sludge. Nitrifying bacteria was found to have about 10 times more AGS than activated sludge. The result of microbial community analysis showed that AGS has higher microbial diversity than activated sludge.

In the results of removal efficiency and changes in AGS, we confirmed that the SBR process using AGS can be used to treat the sewage having low carbon/nitrogen ratio by applying short settling time.

\section{Acknowledgments}

This subject is supported by Korea Ministry of Environment as
"Global Top Project" (Project No.: 2016002190006).

\section{References}

1. Cassidy DP, Belia E. Nitrogen and phosphorus removal from an abattoir wastewater in a SBR with aerobic granular sludge. Water Res. 2005;39:4817-4823.

2. de Kreuk MK, Heijnen JJ, van Loosdrecht MCM. Simultaneous COD, nitrogen, and phosphate removal by aerobic granular sludge. Biotechnol. Bioeng. 2005;90:761-769.

3. Yilmaz G, Lemaire R, Keller J, Yuan Z. Simultaneous nitrification, denitrification, and phosphorus removal from nutrient-rich industrial wastewater using granular sludge. Biotechnol. Bioeng. 2008;100:529-541.

4. Morgenroth E, Sherdeni T, van Loosdrecht MCM, Heijnen JJ, Wilderer PA. Aerobic granular sludge in a sequencing batch reactor. Water Res. 1997;31:3191-3194.

5. Isanta E, Suarez-Ojeda ME, Val del Río A, Morales N, Perez J, Carrera J. Long term operation of a granular sequencing batch reactor at pilot scale treating a low-strength wastewater. Chem. Eng. J. 2012;198-199:163-170.

6. Adav SS, Lee DJ, Lai JY. Treating chemical industries in fluent using aerobic granular sludge: Recent development. J. Taiwan Inst. Chem. Eng. 2009;40:333-336.

7. Gao D, Liu L, Liang H, Wu WM. Aerobic granular sludge: Characterization, mechanism of granulation and application to wastewater treatment. Crit. Rev. Biotechnol. 2011;31:137-152.

8. de Bruin LMM, de Kreuk MK, van der Roset HFR, Uijterlinde C, van Loosdrecht MCM. Aerobic granular sludge technology: An alternative to activated sludge? Water Sci. Technol. 2004;49:1-7.

9. van der Roset HF, de Bruin LMM, Gademan G, Coelho F. Towards sustainable waste water treatment with Dutch Nereda ${ }^{\circledR}$ technology. Water Pract. Technol. 2011;6:wpt2011059.

10. Giesen A, de Bruin LMM, Niermans RP, van der Roest HF. Advancements in the application of aerobic granular biomass technology for sustainable treatment of wastewater. Water Pract. Technol. 2013;8:47-54.

11. Pronk M, de Kreuk MK, de Bruin B, Kamminga P, Kleerebezem $\mathrm{R}$, van Loosdrecht MCM. Full scale performance of the aerobic granular sludge process for sewage treatment. Water Res. 2015;84:207-217.

12. Morales N, Figueroa M, Fra-Vazquez A, et al. Operation of an aerobic granular pilot scale sequencing batch reactor plant to treat swine slurry. Process Biochem. 2013;48:1216-1221. 
13. Tay JH, Liu QS, Liu Y. Characteristics of aerobic granules grown on glucose and acetate in sequential aerobic sludge blanket reactors. Environ. Technol. 2002;23:931-936.

14. Weissbrodt DG, Lochmatter S, Ebrahimi S, Rossi P, Maillard J, Holliger C. Bacterial selection during the formation of early-stage aerobic granules in wastewater treatment systems operated under wash-out dynamics. Front. Microbiol. 2012;3:332.

15. Franklin LB. Wastewater engineering: Treatment, disposal and reuse. 3rd ed. New York: McGraw-Hill; 1991. p. 1275-1279.

16. Ministry of Environment (MOE). The average of sewage. 2017.

17. Roh SH, Chun YN, Lee SY, Cheong H, Lee JW, Kim SI. Effects of fermented leachate of food waste (FLFW) and temperature on nutrient removal in sequencing batch reactor. Environ. Eng. Res. 2008;13:155-161.

18. APHA (American Public Health Association). Standard methods for the examination of water and wastewater. Washington D.C.: APHA; 2005.

19. Pronk M, Abbas B, Al-zuhairy SHK, Kraan R, Kleerebezem $\mathrm{R}$, van Loosdrecht MCM. Effect and behaviour of different substrates in relation to the formation of aerobic granular sludge. Appl. Microbiol. Biotechnol. 2015;99:5257-5268.

20. Winkler MKH, Kleerebezem R, de Bruin LMM, et al. Microbial diversity differences within aerobic granular sludge and activated sludge flocs. Appl. Microbiol. Biotechnol. 2013;97:7447-7458.

21. Gonzalez-Gil G, Holliger C. Dynamics of microbial community structure of and enhanced biological phosphorus removal by aerobic granules cultivated on propionate or acetate. Appl. Environ. Microbiol. 2011;77:8041-8051.

22. Li YM, Zou J, Zhang L, Sun J. Aerobic granular sludge for simultaneous accumulation of mineral phosphorus and removal of nitrogen via nitrite in wastewater. Bioresour. Technol. 2014;154:178-184.

23. Third KA, Burnett N, Cord-Ruwisch R. Simultaneous ni- trification and denitrification using stored substrate (PHB) as the electron donor in an SBR. Biotechnol. Bioeng. 2003;83: 706-720.

24. Yang SF, Tay JH, Liu Y. A novel granular sludge sequencing batch reactor for removal of organic and nitrogen from wastewater. J. Biotechnol. 2003;106:77-86.

25. Ministry of Environment (MOE). The Sewage Law. 2012.

26. Reynolds TD, Richards P. Unit operations and processes in environmental engineering. PWS Publishing Co; 1995

27. Zheng YM, Yu HQ, Liu SJ, Liu XZ. Formation and instability of aerobic granules under high organic loading conditions. Chemosphere 2006;63:1791-1800.

28. Qin L, Liu Y, Tay JH. Effect of settling time on aerobic granulation in sequencing batch reactor. Biochem. Eng. J. 2004;21:47-52.

29. Ferrer M, Martinez-Abarca F, Golyshin PN. Mining genomes and 'metagenomes' for novel catalysts. Curr. Opin. Biotechnol. 2005;16:588-593.

30. He S, Bishio FI, McMahon KD. Bacterial community and "Candidatus Accumulibacter" population dynamics in laboratory-scale enhanced biological phosphorus removal reactors. Appl. Microbiol. 2010;76:5479-5487.

31. Goel RK, Sanhueza P, Noguera DR. Evidence of Dechloromonas sp. participating in enhanced biological phosphorus removal (EBPR) in a bench-scale aerated-anoxic reactor. Proceedings of the Water Environment Federation. 2005. p. 3864-3871.

32. Zilles JL, Peccia J, Noguera DR. Microbiology of enhanced biological phosphorus removal in aerated-anoxic orbal processes. Water Environ. Res. 2002;74:428-436.

33. More RP, Mitra S, Raju SC, Kapley A, Purohit HJ. Mining and assessment of catabolic pathway in the metagenome of a common effluent treatment plant to induce the degradative capacity of biomass. Bioresour. Technol. 2014;153:137-146. 